\title{
Regional Currency and Regional Trade Integration
}

\section{Huidong $\mathrm{He}^{*}$}

Department of Land Economy, University of Cambridge, UK

*Corresponding author: Huidong He, Department of Land Economy, University of Cambridge, 19 Silver Street Cambridge, Cambridgeshire CB3 9EU, UK, Tel: +447552985865; E-mail: hh396@cam.ac.uk

Receiving date: Mar 20, 2017, Accepted date: April 14, 2017, Published date: April 20, 2017

Copyright: ( 2017 Huidong $\mathrm{H}$. This is an open-access article distributed under the terms of the Creative Commons Attribution License, which permits unrestricted use, distribution, and reproduction in any medium, provided the original author and source are credited.

\begin{abstract}
This paper put forward the concept of most frequently used regional currency and discovers there is a U-shape between regional trade integration and it. We choose sixteen in this paper which including all types of regional economic cooperation organisations at the national level. When the proportion of most frequently used regional currency is low, the use of this currency impedes the regional trade. But it promotes the regional trade when it passes the bottom of the U-shape. The transaction cost of the currency contributes a lot to explain this U-shape. Currency status and the political game also act as a significant role. While the proportion of the most frequently used regional currency is relatively low, using this currency is detrimental to the regional trade of the global countries.
\end{abstract}

Keywords: Currency; Trade integration; International monetary cooperation

\section{Introduction}

As technology diffuses rapidly, lower transportation costs and instant communication reduce economic barriers among different countries. Distance is no more the most important determinant in the international trade and globalisation has become the prominent feature of the world economy. But along with the strengthening of world multi-polarization, the contradictions under traditional multilateral trade system are becoming apparent and acute which directly accelerate the development of international regional trade integration. As of 8 January 2015, 604 notifications of RTAs (Regional Trade Agreements) had been received by the GATT/WTO. Growing number of RTAs reflects closer trade relationship in the world and more important regional trade integration.

As the development of the regional integration and regionalism, many scholars do a lot of studies on this topic in the recent year. Whalley [1] points out the question why countries seek regional trade agreements and answer with six reasons: traditional trade gains, strengthening domestic policy reform, increased multilateral bargaining power, guarantees of access, strategic linkage, multilateral and regional interplay. $\mathrm{ADB}$ [2] analyses the emergence of Asian regionalism after the 1997 Asian Financial Crisis. Dinan [3] provides a detailed analysis of EU integration. And a plenty of papers focuses on how integration and globalisation affect economic growth, inequity, government consumption $[4,5]$. But until now, nearly no one analyses how currency contributes to the regional trade from the perspective of regional trade rather than bilateral trade. However, whether it is the bilateral trade, regional trade or global trade, there will be a big problem in choosing invoicing currency and settlement currency. Lower transaction cost currency definitely promotes regional trade. Hence we cannot ignore the significant role of currency in the regional trade. In the previous literature about currency and trade, they usually use the gravity model to explain the currency factor on bilateral trade. And the same currency and currency union are the most frequently used proxy variable in the empirical study and it is easy to see that there is a big problem on this definition. In this paper, we put forward the concept of most frequently used regional currency as a proxy variable and try to explain the relationship between local currency and regional trade integration. Though theoretical and empirical analysis, we find regional trade integration declines at first due to the higher transaction cost and political game along with the extending of local currency. But when local currency occupies a large proportion in the region, it will have low transaction cost and some countries can act as coordinators to avoid beggar-thy-neighbor monetary policy in the region which all promote the trade in the region. These results all are proved in the following statement. The remainder of this paper proceeds as follows: literature review and hypothesis development; followed by description of variable measurement and descriptive statistics; and provides empirical model and results; shows the robustness test; finally, concludes the paper.

\section{Literature Review and Hypothesis Development}

Since the 1990s, with the strengthening of world multi-polarization and increasingly acute contradictions under traditional multilateral trade system, regional trade integration quickly becomes a trend in the world. The elimination of trade barriers and booming regional trade agreements would entail a huge shift in global trade patterns. Except for the literature, we mentioned above, World Bank analyses the reasons of booming regional trade agreements and finds that the reduction of artificial spatial barriers usually occurs in the close trading partners which mean close in geographically or large trading volume in the bilateral trade is easier to have lower tariffs and more quota. This will make closer trade partners becoming further closer and easier to gain more trade preferences in the future. Regional trade agreements only provide more convenient trade environment to those who already have large bilateral trade volume. Feenstra [6] uses the level of merchandise trade relative to GDP to describe the level of global integration and finds it reach a peak in 1913 and gets back again until the late 1960s. And show that when economies are similar in size, the integration of trade becomes growing. But also ignores the role of currency. The effect of currency in the regional trade is hard to measure, and it is supported by most papers that currency or international monetary cooperation has a substantial positive impact 
Page 2 of 8

on trade from the empirical research about currency and bilateral trade. Helliwell [7] finds that trade between two Canadian provinces is more than twenty times larger than trade between a comparable Canadian province/American state pair mainly because trade occurs inside the Canada using a single currency while two currencies between Canada and America. Rose [8] generalises it from two specific countries to the world and finds the trade between two countries that using the same currency is triple than trade between two countries with different currencies. Transaction cost plays an important role in explaining that. High transaction cost impedes the trade and low transaction cost promotes the trade [9]. But in the currency choice, lower transaction cost may not be the decisive factor, or at least not the only decisive factor [10]. Money is politics, and all currency issues and regional trade agreements cannot do without politics. Economic theory is indeterminate in its ability to account for most monetary policy choices even though the economic globalisation and financial liberalisation develop well in the 21st century because the difference between many plausible policies is ambiguous [11]. Trade protectionism and beggar-thy-neighbor monetary policy make the exchange rate fluctuations more complex and it is hard to predict the principles of the economic theory. In order to create a peaceful and cooperative international environment for domestic development, consultations and negotiations about trade occur which further increase the transaction costs. Friberg and Wilander [12] show that the negotiation is important in the currency choice. Frankel \& Rose (2002) find announcement effect may explain how currency union promotes the bilateral trade. So when analysing the relationship between currency and regional trade integration, political factor is important. In the previous studies, scholars usually focus on the same currency and currency union to explain the relationship between currency and bilateral trade. But both the same currency and currency union are too hard to meet the conditions, and much of the monetary cooperation do not relate to the same currency or establishing a currency union which also contributes a lot to promoting the trade. The same currency in a region means some countries have to lose their monetary sovereignty, lacking an independent monetary policy, which makes it more difficult to the balance payments and becomes more relied on the currency issued country. Establishing a currency union like Eurozone also faces many problems, such as fiscal policies, institutional problems and moral hazard. Optimum currency area sets strict requirements on regional trade, economy, inflation and financial system that make this issue more complex and impossible. In this paper, we talk about this issue in a more general concept and use the proportion of most frequently used regional currency to measure the progress of international monetary cooperation. As for the same currency and currency union, the most frequently used regional currency is the common currency. Other regions also have a dominated currency used most frequently, so this concept measures the international monetary cooperation in a more general way. Moreover, this concept emphasises that currency is a local currency of the issuing country in the region, because countries in the same region usually have the close relationship in economy and trade, and only regional currencies can effectively protect against an assault of international capital. After the US subprime mortgage crisis, a large multitude of countries realises the regional currency is the best choice to protect against an assault of international capital [10].

Though some empirical studies [8], the same currency or currency union has the positive effect on bilateral trade. We think the most frequently used regional currency also has the positive effect on regional trade and promote the regional trade integration. We also consider the inertia in choosing the currency for invoicing or settlement [13]. The extension of the regional currency base may face many problems and do harm to the regional trade at first because other currencies (like US dollar for many regions) occupy a high proportion of currency usage and their transaction costs are lower. But along with the increasing proportion, the regional currency has the lower transaction cost and can serve the region better than other currency. This leads to our hypothesis:

Hypothesis: There is a " $U$-shape" between regional trade integration and the most frequently used regional currency. While the proportion of the most frequently used regional currency is low, using this currency is harmful to the regional trade. But it promotes the regional trade when it passes the bottom of the U-shape and the proportion is relatively large. In the existing literature, the same currency or currency union may promote that the bilateral trade is well testified. But no one explores the possible "U-shape". The fact that the same currency and currency union cannot induct the quadratic terms might be one of the reasons.

\section{Variable measurement and Descriptive Statistics}

\section{Variable definition}

Explained variables: Capannelli et al. [14] use two measures to measure the independence and importance of regional trade. They are intraregional trade share (IT share) and intraregional trade intensity (IT intensity). Intraregional trade share is the regional import and export volume to the total import and export volume, which straight describes the independence and importance. Intraregional trade intensity is a relative variable and we should first calculate regional trade share, which is the total import, and export volume in the region to the import and export volume in the world. Intraregional trade intensity is the intraregional trade share to the regional trade share.

Intraregional trade share is defined as

IT Share $=\left(E X_{\mathrm{ii}}+I M_{\mathrm{ii}}\right) /\left(E M_{\mathrm{i} .}+I M_{\mathrm{i}}\right)$

Intraregional trade intensity is defined as

IT intensity $y_{\mathrm{i}}\left(E X_{\mathrm{ii}}+I M_{\mathrm{ii}}\right) /\left(E M_{\mathrm{i} .+} I M_{\mathrm{i} .}\right) /\left(E X_{. \mathrm{i}}+I M_{. \mathrm{i}}\right) /\left(E M_{. .}+I M_{. .}\right)$

Where $E X_{\mathrm{ii}}$ and $I M_{\mathrm{ii}}$ are the regional export and import volume of region i in region i; $E M i$. and $I M i$. are the total export and import volume of region $\mathrm{i} ; E X_{\mathrm{i}}$ and $I M_{\mathrm{i}}$ are the total export and import volume in region i; $E M_{. .}$and $I M_{. .}$are the total exports and imports volume in the world.

Explaining variables: BIS shows that lower transaction cost through the dollar reflects its prominent role in the turnover of foreignexchange market. Therefore, we use the data about foreign exchange transactions to calculate the proportion of the most frequently used regional currency. Bank for International Settlements publishes Triennial Central Bank Survey of Foreign Exchange and Derivatives Market Activity triennially, which covers the foreign exchange transactions of different currency in the different country. The most frequently used regional currency is defined as the largest foreign exchange transactions regional currency, which the issuing country is in this region. The proportion is the foreign exchange transaction of the most frequently used regional currency to the total transactions. We choose samples after 2001 because euro occurred in 2001. We use the linear relationship with the real effective exchange rate to estimate the missing value. 
Page 3 of 8

Control variables: We use the total GDP of the countries which issues the most frequently used regional currency to the total GDP in the region as one of the control variables to control the different status of the regional currency in different regions. Goldberg and Tille [10] show the economic size of the issuing country contributes a lot to the currency share of invoicing. So it also controls the potential of the regional currency. Lok Sang Ho uses the GDP share rather than trade share because GDP share is more comprehensive and reasonable now. Due to the increasing globalisation, big countries would not be selfsufficient but trade more with the other countries. So GDP share has fewer disadvantages now. And GDP shares not only can show the effect of bilateral trade but also reflect the promoting on the trade though the third country channel. We treat the average country risk in the region as a proxy variable for the regional risk. Generally speaking, high-risk level in the region does harm to the trade with the countries outside the region which leads to higher regional integration level. We also use this variable to control the war or conflict effect on regional trade [15] Banque, 2011, because it will be reflected in the high scores in the average country risk. We use the country risk calculated by Economist Intelligence Unit (EIU). It measures five risk categories: currency, sovereign debt, banking, and political and economic structure across 128 countries, assigning each a rating, which can be compared across regions and over time. 100 means the riskiest and 0 means the least risky.

Trade openness is another control variable. On the one hand, high trade openness means the country positively involves in the world trade and the regional trade may be closer. On the other hand, high trade openness increases the bilateral conflicts or multilateral conflicts, which impede the regional trade [15]. The discussion of trade openness measurement is beyond our paper. We choose the trade volume of both export and import to the GDP as the proxy variable for the trade openness, and it is used by many kinds of literature [16,17]. Feenstra [6] finds similar economic scenario has a high level of trade integration. In this paper, we choose merchandise trade (\% of the GDP), GDP per capita, an urban rate to measure the similar economic indicators. These three variables reflect the trade structure, economic development level and society development level. All the variables are calculated by the standard deviation in the region to measure the differences of the region. It can be compared across regions and over time. Table 1 shows variable definition and measurement, export and import data come from the IMF Direction of Trade Statistics and CEIC Global Database; country risk data come from EIU Country Risk Model; other data come from World Development Indicators.

\begin{tabular}{|c|c|}
\hline Variable & Definition and measurement \\
\hline IT share & Intraregional trade share \\
\hline IT intensity & Intraregional trade intensity \\
\hline Currency & The most frequently used regional currency \\
\hline Currency_2 & Quadratic term of the most frequently used regional currency \\
\hline Dgdp & $\begin{array}{l}\text { The total GDP of the countries which issuing the most } \\
\text { frequently used regional currency to the total GDP in the } \\
\text { region }\end{array}$ \\
\hline Risk & Country risk in the region (average) \\
\hline Trade openness & Trade openness in the region (average) \\
\hline Metrade & $\begin{array}{l}\text { Merchandise trade (\% of the GDP) in the region (Standard } \\
\text { Deviation) }\end{array}$ \\
\hline
\end{tabular}

\begin{tabular}{|l|l|}
\hline GDPpc & GDP per capita in the region (Standard Deviation) \\
\hline Urban rate & Urban rate in the region (Standard Deviation) \\
\hline
\end{tabular}

Table 1: Variable definition and measurement.

\section{Variable descriptive statistics}

Because the data in Africa and Central America is not available, our sample cannot cover the regional economic cooperation organisations in Africa and Central America. We choose sixteen in this paper which including all types of regional economic cooperation organisations at the national level. They are Benelux Economic Union (Benelux), European Union (EU), European Free Trade Association (EFTA), Commonwealth of Independent States (CIS), Eurasian Economic Community (EAEC), Association of Southeast Asian Nations plus China, Japan and Korea (ASEAN+3), Economic Cooperation Organization (ECO), First Agreement on Trade Negotiations among Developing Member Countries of the Economic and Social Commission for Asia and the Pacific (Bangkok Agreement), South Asian Association for regional cooperation (SAARC), Pacific Islands Forum (PIF), Gulf Cooperation Council (GCC), Andean Community (CAN), G3 Free Trade Agreement (G3), North American Free Trade Area (NAFTA), MERCOSUR, Asia-Pacific Economic Cooperation (APEC). Table 2 shows the descriptive statistics of major variables. The proportion of the most frequently used regional currency ranges from 0.18 to 0.96 in different regions. There is a huge gap mainly because US dollar as an international currency usually occupies a large proportion in the region, nearly $100 \%$. As for intraregional trade share and intraregional trade intensity, there are also differences among these regions, which mean trade integration is different though they are all economic cooperation organisations. Besides, in some of the region, countries inside the region differ greatly in industrial structure, trade structure and economic development level while some are nearly the same.

\begin{tabular}{|l|l|l|l|l|l|}
\hline Variable & Observations & Mean & Std. Dev & Min & Max \\
\hline IT share & 208 & 0.1987 & 0.2107 & 0.0064 & 0.7206 \\
\hline IT intensity & 208 & 3.9005 & 4.31 & 0.3141 & 22.069 \\
\hline Currency & 208 & 0.5842 & 0.214 & 0.1786 & 0.9633 \\
\hline Currency2 & 208 & 0.3881 & 0.2522 & 0.0319 & 0.9279 \\
\hline Dgdp & 208 & 0.6609 & 0.2161 & 0.1033 & 1 \\
\hline Risk & 208 & 41.7561 & 11.7338 & 12.5 & 61 \\
\hline $\begin{array}{l}\text { Trade } \\
\text { openness }\end{array}$ & 206 & 0.869 & 0.3763 & 0.375 & 2.213 \\
\hline Metrade & 192 & 0.297 & 0.2107 & 0.0537 & 0.9273 \\
\hline GDPpc & 208 & 11.77 & 10.57 & 0.6221 & 42.82 \\
\hline Urban rate & 208 & 0.1626 & 0.0899 & 0.0115 & 0.3534 \\
\hline
\end{tabular}

Table 2: Descriptive statistics for major variables.

Table 3 presents some data about the proportion of the most frequently used regional currency, intraregional trade share and intraregional trade intensity in 2001 and 2013 of all the regional economic cooperation organisation mentioned in this paper. During 
Page 4 of 8

these twelve years, the most frequently used regional currency remains integration, intraregional trade share changes comparatively smaller the same, but the proportion has changed greatly. As for the trade than intraregional trade intensity.

\begin{tabular}{|c|c|c|c|c|c|}
\hline Region & $\begin{array}{l}\text { The most frequently used } \\
\text { regional currency }\end{array}$ & Year & $\begin{array}{l}\text { The proportion of the most } \\
\text { frequently used regional } \\
\text { currency }\end{array}$ & Intraregional trade share & $\begin{array}{l}\text { Intraregional trade } \\
\text { intensity }\end{array}$ \\
\hline \multirow[t]{2}{*}{ Benelux } & Euro & 2001 & 0.6818 & 0.1374 & 2.1499 \\
\hline & & 2013 & 0.5281 & 0.1537 & 2.7916 \\
\hline \multirow[t]{2}{*}{ EU } & Euro & 2001 & 0.4871 & 0.6606 & 1.703 \\
\hline & & 2013 & 0.4175 & 0.6353 & 2.0145 \\
\hline \multirow[t]{2}{*}{ EFTA } & Swiss Franc & 2001 & 0.2915 & 0.0074 & 0.3697 \\
\hline & & 2013 & 0.2689 & 0.0082 & 0.4564 \\
\hline \multirow[t]{2}{*}{ CIS } & Russian Ruble & 2001 & 0.4336 & 0.1859 & 10.0872 \\
\hline & & 2013 & 0.7927 & 0.1881 & 5.4504 \\
\hline \multirow[t]{2}{*}{ EAEC } & Russian Ruble & 2001 & 0.4336 & 0.1005 & 6.4193 \\
\hline & & 2013 & 0.7927 & 0.1195 & 3.9394 \\
\hline \multirow[t]{2}{*}{ ASEAN“10+3” } & Yen & 2001 & 0.5174 & 0.3406 & 1.8631 \\
\hline & & 2013 & 0.4418 & 0.3519 & 1.4 \\
\hline \multirow[t]{2}{*}{ ECO } & Turkish Lira & 2001 & 0.2735 & 0.0451 & 3.5813 \\
\hline & & 2013 & 0.5754 & 0.0846 & 4.0088 \\
\hline \multirow[t]{2}{*}{ Bangkok Agreement } & Korean Won & 2001 & 0.6467 & 0.0934 & 1.2712 \\
\hline & & 2013 & 0.3246 & 0.1189 & 0.7194 \\
\hline \multirow[t]{2}{*}{ SAARC } & Indian Rupee & 2001 & 0.8206 & 0.0408 & 3.7226 \\
\hline & & 2013 & 0.8199 & 0.0398 & 1.5684 \\
\hline \multirow[t]{2}{*}{ PIF } & Australian Dollar & 2001 & 0.4578 & 0.0675 & 4.5414 \\
\hline & & 2013 & 0.4408 & 0.048 & 3.0788 \\
\hline \multirow[t]{2}{*}{ GCC } & Saudi Riyal & 2001 & 0.2079 & 0.0649 & 3.447 \\
\hline & & 2013 & 0.1795 & 0.053 & 1.2423 \\
\hline \multirow[t]{2}{*}{ CAN } & Colombian Peso & 2001 & 0.5953 & 0.0889 & 20.7218 \\
\hline & & 2013 & 0.5644 & 0.0772 & 10.4573 \\
\hline \multirow[t]{2}{*}{ G3 } & Mexico Yuan & 2001 & 0.9542 & 0.0221 & 0.6861 \\
\hline & & 2013 & 0.8771 & 0.0219 & 0.7922 \\
\hline \multirow[t]{2}{*}{ NAFTA } & US Dollar & 2001 & 0.9382 & 0.471 & 2.1592 \\
\hline & & 2013 & 0.8907 & 0.4131 & 2.7278 \\
\hline \multirow[t]{2}{*}{ MERCOSUR } & Brazilian Real & 2001 & 0.9633 & 0.1885 & 13.6231 \\
\hline & & 2013 & 0.6829 & 0.1478 & 7.9747 \\
\hline \multirow[t]{2}{*}{ APEC } & US Dollar & 2001 & 0.9421 & 0.7128 & 1.5471 \\
\hline & & 2013 & 0.8927 & 0.664 & 1.3991 \\
\hline
\end{tabular}

Table 3: Major variables in 2001 and 2003 of all regions. 
Page 5 of 8

\section{Empirical Model and Results}

\section{Empirical model}

We use panel data regression model to do the empirical research in this paper and treat the trade integration as explained variable, the proportion of the most frequently used regional currency and its quadratic term as the main explaining variable. We estimate the following model:

integaration $_{\mathrm{it}}=\beta_{0}+\beta_{1}$ currency $_{\mathrm{it}}+\beta_{2}$ currency $_{\mathrm{it}}+\beta_{3} D g d p_{\mathrm{it}}+\beta_{4}$ risk $_{\mathrm{it}}$ $+\beta_{5}$ tradeopenness $_{\mathrm{it}}+\beta_{6}$ metrade $_{\mathrm{it}}+\beta_{7}$ FDIGDP $P_{\mathrm{it}}+\beta_{8} G D P p c_{\mathrm{it}}$ $+\beta_{9}$ urbanrate $_{\mathrm{it}}+\lambda_{\mathrm{i}}+u_{\mathrm{t}}+\varepsilon_{\mathrm{it}}$

Where integration means two ways to measure trade integration which is intraregional trade share and intraregional trade intensity, $i$ represents the region, $t$ represents the year, is the unobservable area factors, is the unobservable time factors, is the random disturbance term.

To test our hypothesis that there is a " $\mathrm{U}$-shape" between regional trade integration and the proportion of the most frequently used regional currency, we employ the fixed effect model to estimate the coefficient. We expect a negative coefficient on the proportion of the most frequently used regional currency while a positive coefficient on its quadratic term.

\section{Empirical results}

Table 4 provides four regression results. The explained variable in column (1) and column (2) is intraregional trade share while it is intraregional trade intensity in column (3) and column (4). The explaining variables in column (1) and column (3) are only the proportion of the most frequently used regional currency and its quadratic term while control variables are added to the column (2) and column (4).

As shown in the four regressions, there is a significant " $U$-shape" between regional trade integration and the proportion of the most frequently used regional currency because the estimated coefficient on both the proportion of the most frequently used regional currency and its quadratic term are statistically significant at $1 \%$ level whether the control variables are added to the regressions or not. When the proportion of the most frequently used regional currency is low, increasing proportion may impede the regional trade development at first. And when the proportion passes the bottom of the "U-shape", its increasing can promote the trade and upgrade the level of regional trade integration.

\begin{tabular}{|c|c|c|c|c|}
\hline & (1) & (2) & (3) & (4) \\
\hline Variable & IT share & IT share & IT intensity & IT intensity \\
\hline \multirow{2}{*}{ Currency } & $-0.280^{\star \star *}$ & $-0.304^{* * *}$ & $-30.03^{* * *}$ & $-19.11^{\star \star *}$ \\
\hline & -0.0646 & -0.0686 & -6.472 & -6.011 \\
\hline \multirow{2}{*}{ Currency2 } & $0.222^{* \star *}$ & $0.236^{* \star *}$ & $22.76^{\star \star \star}$ & $14.05^{\star \star *}$ \\
\hline & -0.0534 & -0.0567 & -5.356 & -4.961 \\
\hline \multirow{2}{*}{ Dgdp } & & -0.0247 & & $-3.840^{*}$ \\
\hline & & -0.0259 & & -2.269 \\
\hline \multirow{2}{*}{ Risk } & & -0.0003 & & $0.145^{\star \star \star}$ \\
\hline & & -0.0003 & & -0.0262 \\
\hline \multirow{2}{*}{ Tradeopenness } & & $0.0772^{\star * *}$ & & 1.334 \\
\hline & & -0.0221 & & -1.931 \\
\hline \multirow{2}{*}{ Metrade } & & $-0.117^{* * *}$ & & $-4.969^{*}$ \\
\hline & & -0.0302 & & -2.646 \\
\hline \multirow{2}{*}{ GDPpc } & & $-0.000747^{\star *}$ & & $-0.110^{* * *}$ \\
\hline & & -0.0003 & & -0.0299 \\
\hline \multirow{2}{*}{ Urbanrate } & & 0.0438 & & $-67.44^{* * *}$ \\
\hline & & -0.199 & & -17.44 \\
\hline \multirow{2}{*}{ Constants } & $0.277^{\star \star \star}$ & $0.283^{\star \star \star}$ & $12.64^{* \star *}$ & $18.74^{\star \star *}$ \\
\hline & -0.018 & -0.0444 & -1.806 & -3.89 \\
\hline Observations & 208 & 192 & 208 & 192 \\
\hline
\end{tabular}


Page 6 of 8

\begin{tabular}{|l|l|l|l|l|}
\hline R-squared & 0.091 & 0.22 & 0.11 & 0.375 \\
\hline${ }^{*},{ }^{* *}$ and ${ }^{* * *}$ denote statistical significance level at $10 \%, 5 \%$ and $1 \%$, respectively. \\
\hline
\end{tabular}

Table 4: Main empirical results.

The "U-shape" between regional trade integration and the proportion of the most frequently used regional currency is related to its transaction costs, currency status in the world and political factors. After the breakdown of the Bretton Woods System, only a few countries choose to establish a floating exchange rate regime and many countries still regard US dollar as an anchor currency in the world. In the late twentieth century, some countries in Africa and Latin America started establishing dollarization to stabilise the domestic economy, enhance international trade and save the cost of foreign reserve. So dollar occupied a dominant status in the world of nearly all regions. Using US dollar directly for trade invoicing and settlement can avoid exchange rate risk and reduce the transaction cost. When the proportion of the most frequently used regional currency is low in a region, the transaction cost is higher than US dollar that we have to exchange in different currencies and do risk prevention which requires both time and money. For this reason, the extending proportion of the most frequently used regional currency in the region does harm to the regional trade instead of promoting.

Although it is costless to use US dollar during the trade, you need to pay back the lower transaction cost ultimately. First of all, it makes the countries in the region relied more on US economy if US dollar used very often in the region. And once there is something wrong in the US economy, its business cycle and monetary policy will deeply affect the countries in the region. Many countries are in a stage of rapid economic development before the US subprime mortgage crisis. But they are also influenced by this crisis due to the overly dependent on US dollar which is unwilling to accept for most. So reforming the existing monetary system structure in the region and even in the world, reducing the dependence on a sovereign currency has become the consensus of the market. Second, if the country carries out dollarization, there is no dependence on monetary policy and exchange rate policy. America would not consider dollarization countries when setting policies. Also, dollarization countries cannot use monetary policy and exchange rate policy to finance the budget deficits and balance the payments. Although no dollarization, there is a big problem when facing invoicing and settlement because the US dollar exchanges rate fluctuation brings much instability. In addition, one of the purposes of regional economic cooperation is to make up for the disadvantages of a single country, expand their voice in the world and jointly maintain the region common interests [18]. Using regional currency can effectively enhance the economic ties between the countries in the region and make the region more competitive in the world market. The cost and benefit of the currency union changed according to the environment [19], and the cost and benefit of the regional currency are changeable too. With the low transaction cost, US dollar provided a "safe haven" for the world development before 2008. But as the US subprime mortgage crisis spread all over the world, more and more countries realise using regional currency is important in trade development and economic independence. At first, maybe the transaction cost is relatively high because of the lower proportion. But as the increasing proportion of the most frequently used regional currency, this currency can also reduce the transaction cost and further better serve the economic development in the region. The same currency and the currency union that discussed in the previous paper can also be explained by our theory. No matter the same currency or the currency union, the directly promoting effort to the trade because it can quickly pass the bottom of the "U-shape". Compared to the process of increasing the proportion of regional currency using, the same currency and currency union have higher institutional cost and impaired the strength of monetary policy tools which may lead to economic upheaval and unbalanced payments. It is also the reason why the same currency and currency union are hard to spread (Table 5).

\begin{tabular}{|c|c|c|c|c|}
\hline & (9) & (10) & (11) & (12) \\
\hline Variables & IT share & IT share & IT intensity & IT intensity \\
\hline \multirow{2}{*}{ Lag explained variable } & $1.028^{* * *}$ & $0.740^{* \star *}$ & $0.949^{\star \star \star}$ & $0.895^{\star \star \star}$ \\
\hline & -0.0297 & -0.161 & -0.0031 & -0.0194 \\
\hline \multirow{2}{*}{ Currency } & $-0.0500^{\star \star *}$ & $-0.0801^{\star *}$ & $-4.343^{\star \star \star}$ & $-14.40^{*}$ \\
\hline & -0.0117 & -0.0372 & -0.261 & -7.954 \\
\hline \multirow{2}{*}{ Currency2 } & $0.0407^{\star * \star}$ & $0.0847^{* *}$ & $4.997^{\star \star \star}$ & $14.24^{*}$ \\
\hline & -0.0124 & -0.0332 & -0.131 & -8.049 \\
\hline \multirow{2}{*}{ Dgdp } & & $0.114^{* *}$ & & 0.759 \\
\hline & & -0.05 & & -2.909 \\
\hline \multirow{2}{*}{ risk } & & 0.00039 & & -0.0041 \\
\hline & & -0.0004 & & -0.0436 \\
\hline
\end{tabular}


Page 7 of 8

\begin{tabular}{|c|c|c|c|c|}
\hline \multirow{2}{*}{ Tradeopenness } & & -0.0009 & & -2.003 \\
\hline & & -0.0236 & & -2.201 \\
\hline \multirow{2}{*}{ Metrade } & & 0.0318 & & 2.64 \\
\hline & & -0.036 & & -3.597 \\
\hline \multirow{2}{*}{ GDPpc } & & $-0.000588^{*}$ & & 0.00051 \\
\hline & & -0.0004 & & -0.0381 \\
\hline \multirow{2}{*}{ Urbanrate } & & $-3.069^{*}$ & & -18.26 \\
\hline & & -1.739 & & -14.63 \\
\hline \multirow{2}{*}{ Constants } & 0.00715 & $0.472^{*}$ & $0.695^{* * *}$ & 6.793 \\
\hline & -0.0076 & -0.269 & -0.149 & -5.261 \\
\hline AR1 & 0.0199 & 0.0618 & 0.0275 & 0.0426 \\
\hline AR2 & 0.2909 & 0.1815 & 0.1205 & 0.1578 \\
\hline Sargan test & 1 & 1 & 1 & 1 \\
\hline
\end{tabular}

Table 5: Robustness test (System GMM)

Reconsider this problem from a political point of view, when the proportion of the most frequently used regional currency is low, many local currencies compete for the regional currency. Some country in the region may make policy which has negative externalities and many negotiations and consultations occur to smooth it. And all of that is for the competition of the regional currency. It may be thought irrational from the economic view, but it is true and ignoring political factors may lead to wrong policy. So these policy shock and the political game definitely impede trade and it is one reason for why regional currency does harm to the trade at first. When the most frequently used regional currency rises up to an invincible position, the issuing country acts as a leader of monetary in the region that contributes a lot to cooperation and coordination among countries, preventing beggar-thy-neighbor monetary policies and promoting the regional trade integration. In addition, the issuing country once has an invincible position; it tends to sacrifice some its own interests to maintain the regional interests [20]. This means the region will have higher trade integration, more stable financial market and more rapid economic development when the proportion of the most frequently used currency is high.

\section{Robustness Test and Discussion}

To make sure the robustness of the results, we use the Dynamic GMM to test and solve the endogeneity problem. Difference GMM may lose information during the estimation and easier to occur weak instruments, so we use System GMM introduced by Blundell \&bond to do our regression. It uses the lagged value of the explained variable as instruments to do the estimation. The results are the same as we did before. Also, we do the testing for the model specification; ArellanoBond test shows that the disturbance term is not autocorrelated and accords with the consistency of the System GMM. Sargan test declares all the instrument variables are effective.

\section{Conclusion}

Many scholars focus on the same currency and currency union to study the currency effect on bilateral trade in the previous paper. We use the proportion of the most frequently used regional currency as a proxy variable to measure the international monetary cooperation and try to explain the relationship between the regional trade integration and it. For the previous study, it is not realistic to set a quadratic term in the regression to test the "U-shape". In this paper, we find there is a significant "U-shape" between the proportion of the most frequently used regional currency and regional trade integration. While the proportion of the most frequently used regional currency is low, using this currency is harmful to the regional trade. But it promotes the regional trade when it passes the bottom of the U-shape and the proportion is relatively large. The robustness test supports our hypothesis. This result is unexpected but reasonable. The transaction costs contribute a lot to explain the "U-shape". It will be costly to use regional currency when the proportion is low. But it will be less costly and cheaper eventually with the increasing of the proportion. Then currency status is another influence. International currency is more stable than other currency and regional currency will raise its status to the international currency with the increasing of the proportion. At last, currency and monetary cooperation are inseparable from political game and policy. In the beginning of the regional currency extending, political negotiation and regional currency competition harm the development of regional trade. But once the most frequently used regional currency rises up to an invincible position, it tends to sacrifice some its own interests to maintain the regional interests, which will promote the regional trade.

\section{References}

1. Whalley J (1998) Why do countries seek regional trade agreements? University of Chicago Press. 
Page 8 of 8

2. Asian Development Bank (2008) Emerging Asian Regionalism. A Partnership for Shared Prosperity.

3. Dinan D (2004) Ever closer union: an introduction to European integration. Boulder, USA.

4. Beer L, Boswell $\mathrm{T}$ (2001) The effects of globalisation on inequality: a cross-national analysis.

5. Dreher A (2006) Does globalisation affect growth? Evidence from a new index of globalisation. Applied Economics 38: 1091-1110.

6. Feenstra RC (1998) Integration of trade and disintegration of production in the global economy. The Journal of Economic Perspectives 12: 31-50.

7. Helliwell JF (1996) Do borders matter for social capital? Economic growth and civic culture in US states and Canadian provinces. National Bureau of Economic Research.

8. Rose AK (2000) One money, one market: the effect of common currencies on trade. Economic Policy 15: 8-45.

9. Krugman P (1980) Scale economies, product differentiation, and the pattern of trade. The American Economic Review 70: 950-959.

10. Goldberg LS, Tille C (2008) Vehicle currency use in international trade. Journal of International Economics 76: 177-192.

11. Kirshner J (2003) Money is politics. Review of International Political Economy 10: 645-660.
12. Friberg R, Wilander F (2008) The currency denomination of exports-a questionnaire study. Journal of International Economics 75: 54-69.

13. Rey H (2001) International trade and currency exchange. The Review of Economic Studies 68: 443-464.

14. Capannelli G, Lee JW, Petri PA (2009) Developing indicators for regional economic integration and cooperation.

15. Martin P, Mayer T, Thoenig M (2008) Make trade, not war? The Review of Economic Studies 75: 865-900.

16. Bonfiglioli A (2008) Financial integration, productivity and capital accumulation. Journal of International Economics 76: 337-355.

17. Edwin L (2012) The Emergence of a Major Invoicing Currency.

18. Krugman PR (1991) Geography and trade. MIT press.

19. Artis M (2002) Currency interdependence: what economics has to say. Journal of Public Policy 22: 111-118.

20. Kirshner J (1997) Currency and coercion: the political economy of international monetary power. American Political Science Review 91: 236-237. 